\title{
Typology of Export Specialization of the Russian Regions
}

\author{
Kashbrasiev R.V. \\ Kazan Federal University, Institute of Management, Economics and Finance, Kazan, 420008, Russia \\ Stepin A.G. \\ Kazan Federal University, Institute of Management, Economics and Finance, Kazan, 420008, Russia
}

Shtanchaeva M.R.

Kazan Federal University, Institute of Management, Economics and Finance, Kazan, 420008, Russia

Maklakova N.V.

Kazan Federal University, Institute of Language, 420008, Kazan, Russia

\section{Doi:10.5901/mjss.2014.v5n24p453}

\begin{abstract}
The work carries out the primary analysis of the mass economic-geographical information which includes: 1) the stage of systematization using the methods of typing and zoning, 2) the analysis of the existing sectorial and regional characteristics of the foreign trade activity of the Russian Federation. Balances of foreign trade operations of all organizations as parts of the subjects of the Russian Federation that carry out these operations in the period from 2000 to 2010 within major product groups, are in the basis of the typing. Combining the indicators of foreign trade in seven groups is according to state statistics: food supplies, supply of fuel and energy components, petrochemical products, the supply of timber and related forest products, supply of products of the metallurgical and machine-building industries, as well as the group that unites all the other types of products. In the result of the research of the branch structure of the regions' export we managed to allocate 8 types of subjects of the Russian Federation, where the regions without prevalent specialization belong to the 8th type.
\end{abstract}

Keywords: export, typing, sectorial structure of the region, foreign economic activity, competitiveness.

\section{Introduction}

The modern stage of development of the Russian economy sets the state a number of important tasks. Optimization of foreign economic activity is one of these tasks [1]. According to the existing terminology, foreign trade, capital flow, the provision of services of different nature (productive and non- productive), international tourism and others belong to the main types of foreign economic relations. Among the main indicators that characterize the foreign economic activity of the state, foreign trade, exports, imports, trade balance (balance of foreign trade), export and import quotas (the share of exports and imports in GDP) and others are of particular importance [2].

The collapse of the USSR in the early 90 s of the $20^{\text {th }}$ century aggravated the economic crisis in our country, led to breakdown of traditional economic ties. Since 1999, the trade turnover, exports and imports in Russia gradually began to increase, and now our country has positive trade balance. Development of foreign trade is possible only if the country has the corresponding export potential which is understood as possibility of the country to export (sell abroad) available or produced resources, goods and services [3]. At the same time, today the exports of Russia has a distinct resource orientation, and Russia is on the so-called "raw needle" [4, 5].

The paper presents the preliminary analysis of the mass economic-geographical information which includes the stage of systematization using the methods of typing and zoning; the analysis of the existing sectorial and regional characteristics of the foreign trade activity of the Russian Federation. The typology of the regions of Russia by industries of export specialization in order to assess their participation in international production networks is the aim of the work. 


\section{Methodology of the Research}

The primary analysis of mass economic and geographic information traditionally includes the stage of systematization which, in its turn, is always connected with the use of methods of typing and zoning. The analysis of the existing sectorial and territorial characteristics of Russian foreign trade activity, which, in the context of this study, is considered, firstly, a special stimulus of technical upgrading of the modernizing economy, and, on the other hand, the constant growth of the standard of living of the population, is not an exception.

It is necessary to say that the use of typology as the method of scientific research is well represented in the literature of recent years: Lipscomb and Kashbrasiev, 2008, Kontorovich, Eder, and Nemov, 2012, Chernova, 2013, Gusev, $2013[1,5-8]$.

Balances of foreign trade operations of all organizations as the part of the subjects of the Russian Federation that carry out these operations during the period (from 2000 to 2010) separately for the major product groups, are in the basis of our typing. According to government statistics, there is the combining of foreign trade activity indicators into groups, among which seven groups are outlined: food supplies, supply of fuel and energy components, petrochemical products, the supply of timber and related forest products, supply of products of the metallurgical and machine-building industries, as well as the group that unites all the other types of products [9]. Their ratio can vary significantly depending on the level of development of the country, internal and external conditions. In Russia, the supply of fuel and energy products plays the leading role (fig. 1).

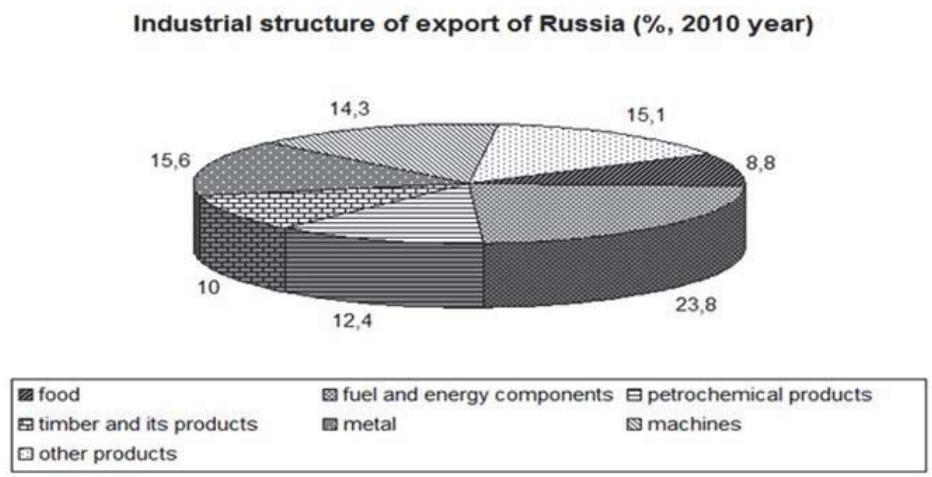

Fig. 1. Industrial structure of export of Russia $(\%, 2010)$

Indicators of territorial and sectorial structures of foreign trade activities of the entity (entities) were calculated on the basis of the balance of foreign trade, and it allowed to calculate the entire set of paired coefficients of the linear correlation for each pair of corresponding sectorial structures of foreign trade activity of each of the pairs of entities. Anderson D., Sweeney D., Williams T. say that when the decision-maker is sure about the reliability of connection between two variables, in such cases it is possible to use the correlation analysis as one of statistical methods; it defines the bonding strength between two variables [10]. Applied to our problem to be solved, the authors propose a new method to determine the pair correlation between sectorial export structures of two compared subjects $i$ and $j$, which can be represented by the following formula:

$$
r_{x^{(i)} x(j)}=\frac{\frac{1}{n} \sum_{k=1}^{n} x_{k}^{(i)} x_{k}^{(j)}-\bar{x}^{(i)} \bar{x}(j)}{\sigma_{x^{(i)}} \cdot \sigma_{x^{(j)}}} .
$$

where the specific gravity values of the $k$ sectorial structural position of export $(k=1,2, \ldots, n)$, accordingly, for $i$ and $j$ entities are represented by $x_{k}^{(i)}$ и $x_{k}^{(j)}$; values of $\bar{x}^{(i)}$ и $\bar{x}^{(j)}$ of average relative share of the export structure, accordingly, for $i$ and $j$ entities, which are calculated by the formula (for $s$ - entity $(s=1,2, \ldots, \mathrm{m})$ ):

$$
\bar{x}^{(i)}=\frac{1}{n} \sum_{k=1}^{n} x_{k}^{(5)},
$$

and by $\sigma_{x^{(i)}}$ и $\sigma_{x(j)}$ values - standard mean square deviation of the structure of export, accordingly, for $i$ and $j$ entities which are calculated by the formula (for s- entity):

$$
\sigma_{x \oplus}=\sqrt{\frac{\sum_{k=1}^{n}\left(x_{k}^{(S)}-\bar{x}^{(S)}\right)^{2}}{n}} .
$$

The number $m$ defines the number of subjects of the Russian Federation, and $n$ - the number of structural 
positions of export of the region - the RF subject.

Besides, the coefficients of correlation between the subject and the index of the averaged sectorial structure were calculated on average in Russia. These coefficients, as well as the visual comparison of the similarity of structures allowed to implement the typing subjects of subjects of the Russian Federation by indicators of foreign trade. Besides, the degree of compliance of the territorial structures of export to the corresponding structure of the foreign trade activity was determined by the methods of correlation analysis. Typing of the dynamic changes of indicators of foreign trade activity of subjects of the Russian Federation is another direction of the primary analysis of the foreign trade activity of the Russian Federation. For this we used the methods of determining the average indicators of annual growth and increase of indicators of entities of this activity.

\section{Results of the Research}

8 types of subjects were determined in the subjects' sectorial structure of export. It is necessary to say that the distribution of subjects by types is uneven. Fuel and energy type is clearly the predominant one (table 1).

Table 1. The distribution of the Russian regions by types of export specialization

\begin{tabular}{|l|c|}
\hline Type & Number of regions \\
\hline Type 1 - food & 6 \\
\hline Type 2 - fuel and energy components & 23 \\
\hline Type 3 - petrochemical products, & 9 \\
\hline Type 4 - timber and its products & 6 \\
\hline Type 5 - metal & 12 \\
\hline Type 6 - machines & 12 \\
\hline Type 7 - other products & 9 \\
\hline Type 8 - absence of clear specialization & 5 \\
\hline
\end{tabular}

In general, the qualitative composition of the types of regions by the prevailing export specialization is as follows:

- type 1: food. It defines entities in the export structure of which there is prevalence of food exports share. It's remarkable that the majority of them are regions of the Far East that work for the perspective Asian region. In addition to seafood, some Far East regions have good potential of export of agriculture products;

- type 2: fuel and energy. It defines the entities, in the export structure of which there is prevalence of share of fuel and energy resources export (coal, oil, gas). In the typing of exports it is the largest group. The subjects of the Russian Federation that have different natural resources of energy nature -coal, gas and oil - are included in this group [11]. Two subjects of the Russian Federation -Moscow and St. Petersburg -that don't have their own natural resources but anyway have "controlling interest" of production and export of energy resources in the country, are an exception [12]. This group of subjects has regional structure of industry exports that almost coincides with national structure in which $4 / 5$ of value of exported production falls to the share of two rough, primarily export industries - fuel and energy exports (69\% of exports value) and exports of metal and handicrafts (10\%) [13];

- type 3 - oli and gas. It defines those subjects, in the export structure of which the share of petrochemicals and organic synthesis prevails. Despite the considerable attention paid to the development of this part of the economic complex of the country, it is clear that now this sector of the economy plays the significant role in the saturation of the domestic market. It is possible that the deepening of such analysis in the context of individual mono- and poly-sectorial "clusters" will allow to assess their contribution into the export of petrochemical products and organic synthesis, whereas in the export of production of "the covering" subject the similar weight decreases;

- $\quad$ type 4 - forest. It is formed by subjects, in the total export of which the relative weight of supply of wood and its products is rather large [14]. The subjects of the south of the Far Eastern Federal District in their supply practically do not focus on trade by timber products with the neighboring countries. Gradual depletion of forest resources in this part of the country will require to solve the whole set of tasks of diversification of "forest" orientation of development of this part of the country;

- type 5 - metallurgical. It is formed by the subjects, the prevailing share of the funds received from the export of which is connected with the sales, in the first place, of metal and semi-finished products of it. First of all, it is 
the traditional centers of production of black metal, as well as smelting centers of non-ferrous metals. It is necessary to say that in this group there are regions, in which, alongside with the industry that determines the export focus, there are other sectors with the significant relative weight of regional exports;

- type 6 - machine-building. It is formed by regions, in which the production of machine-building industries is the prevalent item in the income from export. Those subjects, in which the development of industries of the military-industrial complex is traditionally supported, are included in this group of subjects, as far as the other sub-industries of machinery engineering can not currently dictate the competitive terms to the world machinebuilding complex and that are focused to the national market in the manufacturing and sales of production. However, in conditions of possible fuel and energy revolution that will carry out the re-orientation to new types of energy, the gradual transition from the raw material orientation of the national economy to the creative one, with the high level of national engineering, is possible ;

- type 7 - other industries. Subjects whose export is the so-called other production, including production of chemistry, precious gems and jewelry, handicrafts, ornamental semi-precious stone, etc., are the part of this industry. The Republic of Sakha, the total volume of export of products of which considerably exceeds the total volume of export of all other subjects mentioned, is the natural leader among these subjects by export turnover. However, this Republic occupies one of the last places in the group of the most "exporting" subjects by the size of value of exported production. Over the last 30 years in Yakutia there are no conditions for development of rich coal reserves, the increase of production and exports of which could replenish energetic balance of DFO and to raise export status of the republic;

- type 8 - without prevailing specialization. The characteristic feature of the regions of this type is in approximately equal shares of several industries in regional exports, and this does not allow to refer them to some of the above-defined types. Apart from various combinations of prevalence of different industries in the structure of export the regions of this group differ by the lack of fuel-energy exports (except the Altaisky region) (fig. 2).

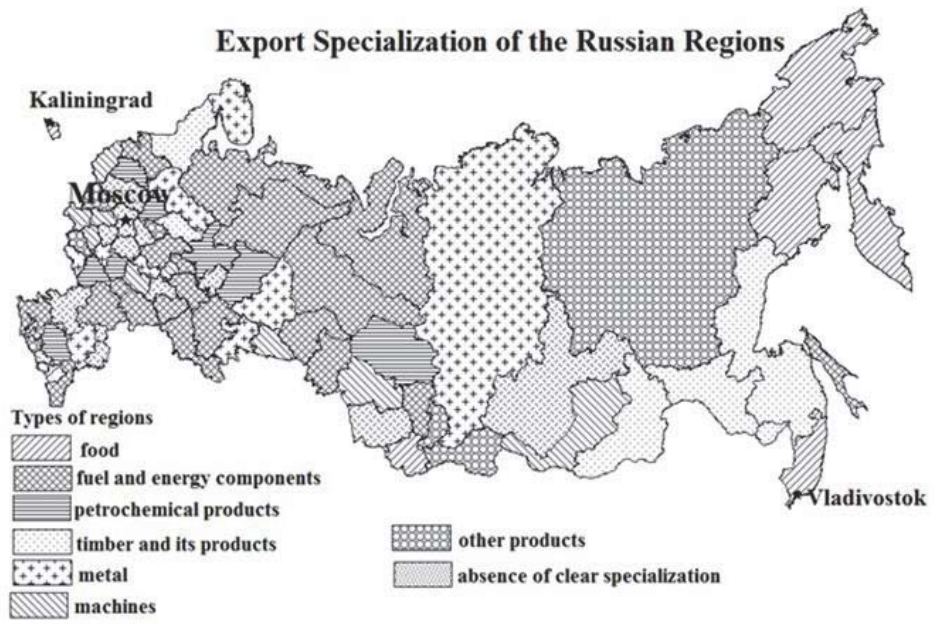

Fig.2. Export Specialization of the Russian Regions

\section{Statements}

The results of the research of the sectorial structure of Russian exports allowed to define 8 types of subjects of the Russian Federation that fairly present peculiarities of the regional exports.

These types of subjects of the Russian Federation by the sectorial structure of exports allow to say that currently the export is a fairly compact system that is connected, first of all, with sales of fuel and energy resources and metal goods outside the country. Exports of forest and its products do not constitute a significant part of export. Our studies show that in general, the export of Russia currently has a distinct resource orientation, and Russia is on the so-called "raw needle."

On the other hand, production works that are directly or indirectly connected to the traditional production of militaryindustrial complex that preserve the scientific and production potential, play the significant role in maintenance of the 
export competitiveness of the national economy. The production of this complex partially re-oriented to civil needs, is more than $10 \%$ of value of national exports.

The study shows that during the period (2000-2010) the amount of the national exports increased by almost 3.8 times. It is necessary to particularly note the development of foreign trade activity of the Sakhalin region, in which the exports for the period increased by more than 27.5 times. This occurred against the background of production and sale of fuel (oil), as well as the all-round development of production and processing of seafood. In distribution of the regions in terms of gross exports there is the extreme asymmetry.

In conclusion, it is necessary to say that the spatial structure of the annual amount of exports in 2010 is almost identical to the similar structure in 2000. The conclusion is quite natural - the country as a whole and in terms of entities continues to be oriented to the raw materials principle of obtaining the foreign income. It continues to "push" the country away from the process of sectorial and territorial modernization and development.

\section{References}

Gusev, A.B. 2013. Economic development strategies of regions of Russia: System crisis and new economic space // Economy of Region, Issue 4, pp.220-237.

Ghimire, S.A, Mukherjee, D.b , Alvi, E.b, 2013. Sectoral aid-for-trade and sectoral exports: A seemingly unrelated regression analysis /I Economics Bulletin, Volume 33, Issue 4, pp.2756-2762.

Polyanskaya, I.G., Yurak, V.V. 2013. Institutions, mechanisms and methods of innovative subsurface resources management // Economy of Region, Issue 1, pp.205-215.

Cehlár, M., Mihok, L. 2013. Regional development in the context of exploitation of mineral wealth of a country // Theoretical and Empirical Researches in Urban Management, Volume 8, Issue 4, pp.60-72.

Kontorovich, A.E., Eder, L.V., Nemov, V.Yu. 2012. Balance of the work of Russia oil industry in 2011 // Neftyanoe Khozyaistvo - Oil Industry, Issue 7, pp.66-70.

Chernova, L.S. 2013. Interrelation between the typology of the RF subjects and methods for the evaluation of the national economic level // Studies on Russian Economic Development, Volume 24, Issue 2, pp.189-198.

Lipscomb, C.A., Kashbrasiev, R.V. 2008. Using County Typologies to Inform Job Tax Credit Policy in Georgia // Review of Regional Studies, 38(2), pp.233-250.

Denmukhametov, R.R., Zjablova, O.V., Shtanchaeva, M.R. 2014. Development factors of Kazan region recreation area. Life Science Journal, Volume 11, Issue 11, pp. 317-320.

Hryshchenko, V.F., Dreval, O.Y., Gryshchenko, I.V. 2012. Organizational \& economic grounds for region's export-import potential management taking into account the requirements of environmental security // Actual Problems of Economics, Volume 133, Issue 7, pp.132-145.

Anderson D., Sweeney D., Williams T. 2010. Statistics for Business and Economics.- West Publishing Company, $670 \mathrm{p}$.

llin, S.A., Kovalenko, V.S., Pastikhin, D.V. 2013. Siberia as a prospective ground for the development of mineral resources by open-cut method // Gorny Zhurnal, Issue 4, pp.30-36.

Franks, D.M., Brereton, D., Moran, C.J. 2013. The cumulative dimensions of impact in resource regions // Resources Policy, Volume 38, Issue 4, pp.640-647.

Tarbaev, M.B. , Khabarov, A.B. 2013. Mineral resources are the basis of industrial development of Komi Republic // Gorny Zhurnal, Issue 9, pp.4-9.

Shishelov, M.A. 2013. The performance of regional timber industry complex // Economy of Region, Issue 2, pp.114-119. 